\title{
Influences of Ridge Width and Foliar Spraying of Amino Acids Compounds on Yield and Quality of Two Faba Bean Cultivars
}

\author{
Hanaa F. Y. Mohamed', Abeer A. Mahmoud', Eman I. Abdel-Wahab² \\ ${ }^{1}$ Botany Department, Faculty of Agriculture, Cairo University, Giza, Egypt \\ ${ }^{2}$ Food Legumes Research Department, Field Crops Research Institute, Agricultural Research Center, Giza, Egypt \\ Email: hanaafatouh@yahoo.com
}

How to cite this paper: Mohamed, H.F.Y., Mahmoud, A.A. and Abdel-Wahab, E.I. (2018) Influences of Ridge Width and Foliar Spraying of Amino Acids Compounds on Yield and Quality of Two Faba Bean Cultivars. Agricultural Sciences, 9, 1629-1651.

https://doi.org/10.4236/as.2018.912114

Received: December 10, 2018

Accepted: December 25, 2018

Published: December 28, 2018

Copyright $(9) 2018$ by authors and Scientific Research Publishing Inc. This work is licensed under the Creative Commons Attribution International License (CC BY 4.0).

http://creativecommons.org/licenses/by/4.0/

\begin{abstract}
A two-year study was carried out at the Agricultural Experiments and Research Station, Faculty of Agriculture, Cairo University, Giza, Egypt, during 2015/2016 and 2016/2017 seasons to evaluate seed yield and quality of two faba bean cultivars to different rates of amino acids compounds under narrow and wide ridges. Two faba bean cultivars Sakha 1 and Masr 3 were grown in two ridge widths 60 and $120 \mathrm{~cm}$ and received five rates of amino acids compounds (Power mix at rates $1.5 \mathrm{~cm} \cdot \mathrm{L}^{-1}$ " $\mathrm{Pm}_{1}$ " and $3.0 \mathrm{~cm} \cdot \mathrm{L}^{-1}$ " $\mathrm{Pm}_{2}$ ", Super mix at rates of $3.5 \mathrm{~cm} \cdot \mathrm{L}^{-1}$ " $\mathrm{Sm}_{1}$ " and $7.0 \mathrm{~cm} \cdot \mathrm{L}^{-1}$ " $\mathrm{Sm}_{2}$ ", as well as, water only "control treatment"). The treatments laid out in a split split plot distribution in randomized complete blocks design in three replications were used. Ridge width was randomly assigned to the main plots, faba bean cultivars were allocated in sub-plots and amino acids compounds were allocated in sub sub-plots. Shoot chemical composition and photosynthesis pigments, as well as, chemical composition in seed traits of faba bean were tested in the laboratories of Plant Physiology Section, Agricultural Botany Department, Faculty of Agriculture, Cairo University, Giza, Egypt. Wide ridge had higher nitrogen $(\mathrm{N})$, phosphorus $(\mathrm{P})$, potassium $(\mathrm{K})$, total sugars and total free amino acids concentrations in faba bean shoot and seeds in addition to chlorophyll a (Chl a) and chlorophyll b ( $\mathrm{Chl} \mathrm{b)} \mathrm{in} \mathrm{faba} \mathrm{bean} \mathrm{shoot,} \mathrm{as} \mathrm{well} \mathrm{as,} \mathrm{most} \mathrm{seed} \mathrm{yield}$ attributes than those of the narrow one. Faba bean cultivar Sakha 1 had higher values of seed yield, yield attributes and quality than Masr 3 that achieved higher seed antioxidants. Also, amino acids compounds affected significantly all studied traits of faba bean plants. $\mathrm{Pm}_{2}$ recorded the highest values of chemical composition in faba bean shoot and seeds. Moreover, $\mathrm{Pm}_{2}$ gave the highest seed yield and yield attributes compared to others. The interaction between ridge width and faba bean cultivar was significant for total sugars and carotenoids concentrations in faba bean shoot and 100-seed weight, as well as, seed $\mathrm{N}$ content. Also, the interaction between ridge width and amino
\end{abstract}


acids compound had significant effects on shoot and seed N, P, K concentrations, number of pods plant ${ }^{-1}$ and seed yield $\mathrm{ha}^{-1}$, as well as, total soluble phenols and total free amino acids concentrations. Moreover, the interaction between faba bean cultivar and amino acids compound had significant effects on shoot $\mathrm{Chl}$ a and $\mathrm{b}$ concentrations, number of seeds $\operatorname{pod}^{-1}$ and seed yield plant $^{-1}$, as well as, seed $\mathrm{N}$, total soluble phenols and total free amino acids concentrations. Wide ridge $\mathrm{x}$ faba bean cultivar $\mathrm{x}$ amino acids compound interaction had significant effects on photosynthesis pigments, number of seeds pod $^{-1}$ and seed yield ha ${ }^{-1}$, as well as, seed $\mathrm{N}$, total sugars, total soluble phenols and total free amino acids concentrations. High seed yield and quality were recorded by growing faba bean cultivar Sakha 1 in wide ridge with foliar spraying at rate of $3.0 \mathrm{~cm} \cdot \mathrm{L}^{-1}$ of power mix. On the other hand, growing faba bean cultivar Masr 3 in narrow ridge with foliar spraying at rate of $3.5 \mathrm{~cm} \cdot \mathrm{L}^{-1}$ of super mix had good antioxidants in faba bean seeds.

\section{Keywords}

Ridge Width, Faba Bean Cultivars, Amino Acids Compounds, Seed Yield, Seed Quality

\section{Introduction}

Legumes in different geographical regions considerably differ in their use, phyto-constituents and nutritive value. It has an important place in the traditional diets of the Mediterranean, Indian, Chinese, English, Middle Eastern, African and South American, and has considerable importance as a low-cost food rich in proteins and carbohydrates [1]. In Egypt, field bean (Vicia faba L.) is one of essential winter field crops due to its protein that is a good alternative compared with expensive meat and fish protein [2]. It is known that seed of this crop can be eaten either fresh or cooked. The most popular dishes of faba bean are Medamis "stewed beans", Falafel "deep fried cotyledon paste with some vegetables and spices", Bissara "cotyledon paste poured onto plates" and Nabet soup "boiled germinated beans" [3]. This protein has high nutritive value and protein contents [4]. According to FAOSTAT [5], China, Ethiopia, France, Egypt and Australia are main faba bean producing countries. However, various processing methods such as roasting, soaking, germination or fermentation decrease the levels of anti-nutritional factors [6]. Unfortunately, faba bean production is affected by different factors such as genotypes and plant distribution, where Abd El-Rahman [7] showed that the interaction between faba bean genotypes and plant distribution had significant effect on plant height, numbers of branches and pods plant ${ }^{-1}$, seed yield plant ${ }^{-1}, 100$-seed weight and seed yield unit area ${ }^{-1}$. Also, Safina [8] found that faba bean cultivar Giza 843 integrated positively with the widest ridge and recorded the highest seed yield ha $\mathrm{h}^{-1}$ compared with the other treatments. 
Concerning to the advantageous belongings foliar spraying of amino acids, foliar spraying treatment of plants with naturally occurring compounds in plant cells is an easy technique and an alternative approach used to reduce mineral nitrogen (N) fertilizers uses. Improving the content of limiting amino acids by breeding seems very difficult since a strong correlation coefficient exists between protein content and the content of individual amino acids [9]. Amino acids contain both acid and basic groups and act as buffers, which help to maintain favorable $\mathrm{pH}$ value within the plant cell [10] and thereby impact plant growth and serve to explain how organic matter promotes soil productivity [11]. According to Rai [12], amino acids are considered as precursors and constituents of proteins. They are participatory in the compilation of other organic compounds, such as amines, alkaloids, vitamins, enzymes and protein [13]. The valuable effects of amino acids improved growth and yield for some legume crops [14] [15] and [16]. Moreover, Zewail [17] demonstrated that foliar application with amino acids at $4 \mathrm{ml} \cdot \mathrm{L}^{-1}$ increased dry weight of shoots and specific growth rate of common bean plant.

A wide variety of antioxidants such as vitamins $\mathrm{C}$ and $\mathrm{E}$, carotenoids, terpenoids and polyphenols contribute to the antioxidant capacity of plant foods [18], where these antioxidants able to protect against reactive oxygen species, which are responsible for reactions underlying many serious diseases [19]. The differences in the phenolic composition and antioxidant activity between faba bean cultivars were observed by Chaieb et al. [20]. Also, phenolic compounds are one of the micro-constituents which have been gaining an increasing interest for their health promoting properties, largely defined by their antioxidant activity [21], but little is known about the antioxidants present in Egyptian faba bean cultivars. Therefore, the objective of this study was to evaluate seed yield and quality of two faba bean cultivars to different rates of amino acids compounds under narrow and wide ridges.

\section{Materials and Methods}

A two-year study was carried out at Giza Agricultural Experiments and Research Station (Latitude $30^{\circ} 00^{\prime} 30^{\prime \prime N}$, Longitude $31^{\circ} 12^{\prime} 43^{\prime \prime E}, 26$ m.a.s.l), Faculty of Agriculture, Cairo University (Egypt), during the two successive seasons 2015/2016 and 2016/2017. This study evaluate seed yield and quality of two faba bean cultivars to different rates of amino acids compounds under narrow and wide ridges. Representative soil samples were taken from each site at the depth of 0 to $30 \mathrm{~cm}$ from the soil surface. The soil analysis of the experimental soil as an average of the two growing seasons 2016 and 2017, indicated that the soil is clay loam (3.95\% coarse sand, $30.83 \%$ fine sand, $28.71 \%$ silt and $36.51 \%$ clay), the $\mathrm{pH}$ (paste extract) is 7.95, the available nutrients in $\mathrm{mg} \mathrm{kg}^{-1}$ are $\mathrm{N}$ (27.45), $\mathrm{P}$ (12.64) and $\mathrm{K}$ (239). The procedure of soil analysis followed the methods of Black [22]. Furrow irrigation was the system irrigation in the region. Maize was the preceding summer crop in both seasons. The substances and the rate of spraying are illustrated in Table 1. 
Table 1. Name, rate, composition and source of the tested amino acids compounds under this study.

\begin{tabular}{ccll}
\hline Compounds name & rate & Composition & Source \\
\hline \multirow{2}{*}{ Power mix } & $1.5 \mathrm{~cm} \cdot \mathrm{L}^{-1}$ & amino acids, riboflavin, cytokinines, gibberellic & General Organization for Agricultural Equalization \\
& $3.0 \mathrm{~cm} \cdot \mathrm{L}^{-1}$ & acid, K citrate and micro-elements & Fund, Agricultural Research Center, Giza, Egypt \\
Super mix & $3.5 \mathrm{~cm} \cdot \mathrm{L}^{-1}$ & amino acids, $\mathrm{Mg}$, natural growth promoters & General Organization for Agricultural Equalization \\
& $7.0 \mathrm{~cm} \cdot \mathrm{L}^{-1}$ & & Fund, Agricultural Research Center, Giza, Egypt \\
\hline
\end{tabular}

Calcium superphosphate $\left(15.5 \% \mathrm{P}_{2} \mathrm{O}_{5}\right)$ was applied during soil preparation at the rate of $357 \mathrm{~kg} \cdot \mathrm{ha}^{-1}$. Faba bean cultivars were planted in $24^{\text {th }}$ and $22^{\text {th }}$ October in 2016 and 2017 seasons, respectively. Faba bean seeds were sown in one and two rows on ridges 60 and $120 \mathrm{~cm}$ width, respectively. The experiment included twenty treatments which were the combinations of two ridge widths (60 and 120 $\mathrm{cm}$ ) with two faba bean cultivars (Sakha 1 and Masr 3) with five amino acids

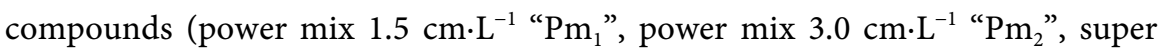
mix $3.5 \mathrm{~cm} \cdot \mathrm{L}^{-1}$ " $\mathrm{Sm}_{1}$ " and super mix $7.0 \mathrm{~cm} \cdot \mathrm{L}^{-1}$ " $\mathrm{Sm}_{2}$ ", as well as, water only "control treatment"). Faba bean cultivars were thinned to two plants spaced at $25 \mathrm{~cm}$ between hills.

With respect to control treatment, faba bean plants received mineral $\mathrm{N}$ fertilizer in form of ammonium nitrate $(33.0 \% \mathrm{~N})$ at rate of $107.1 \mathrm{~kg} \mathrm{~N} \mathrm{ha}^{-1}$ which divided to equal three doses at 20 days (before the first irrigation), 40 days (before the second irrigation) and 60 days (before the third irrigation) from planting. Also, faba bean plants of control treatment received $\mathrm{K}$ sulfate $\left(48.0 \% \mathrm{~K}_{2} \mathrm{O}\right)$ at rate of $119 \mathrm{~kg} \cdot \mathrm{ha}^{-1}$ before the first irrigation.

With respect to four amino acids compounds treatments, faba bean plants received mineral $\mathrm{N}$ fertilizer in form of ammonium nitrate $(33.0 \% \mathrm{~N})$ at rate of $35.7 \mathrm{~kg} \mathrm{~N} \mathrm{ha}^{-1}$ before the first irrigation at 20 days from planting. At 40 days from planting, two treatments only received power mix at rate of $1.5 \mathrm{~cm} \cdot \mathrm{L}^{-1}$ $\left(\mathrm{Pm}_{1}\right)$ and the other treatments received super mix at rate of $3.5 \mathrm{~cm} \cdot \mathrm{L}^{-1}\left(\mathrm{Sm}_{1}\right)$ before the second irrigation. At 60 days from planting, one of the two power mix treatments received $1.5 \mathrm{~cm} \cdot \mathrm{L}^{-1}\left(\mathrm{Pm}_{2}\right)$, meanwhile one of two super mix treatments received $3.5 \mathrm{~cm} \cdot \mathrm{L}^{-1}\left(\mathrm{Sm}_{2}\right)$ before the third irrigation.

The treatments were laid out in a split split plot distribution in randomized complete blocks design in three replications was used. Ridge width treatments were randomly assigned to the main plots, faba bean cultivars were allocated in sub plots and amino acids compounds were allocated in sub sub plots. The area of sub sub-plot was $12.0 \mathrm{~m}^{2}$, each plot consisted of 5 ridges, and each ridge was $4.0 \mathrm{~m}$ in length and $0.6 \mathrm{~m}$ in width. Faba bean cultivars kindly provided by Food Legumes Research Department, ARC, Egypt.

\subsection{The Studied Data}

\section{1) Photosynthesis pigments}

These analyses were done in fresh leaves of faba bean shoot at 75 days from 
planting.

Plant pigments: Fresh leaves was extracted with dimethyl formamide and placed overnight at cool temperature $\left(5^{\circ} \mathrm{C}\right)$. Chlorophyll $(\mathrm{Chl}) \mathrm{a}, \mathrm{b}$, and carotenoids were measured by spectrophotometer at wavelength 663, 647 and $470 \mathrm{~nm}$, respectively. $\mathrm{Chl}$ and carotenoids were calculated according to the equation described by Nornai [23]

$$
\begin{gathered}
\mathrm{Chl} \mathrm{a}=12.70 A_{663}-2.79 A_{647} \\
\mathrm{Chl} \mathrm{b}=20 A_{647}-4.62 A_{663} \\
\text { Carotenoids }=\frac{\left[1000 \times A_{470}-(3.72 \mathrm{Chl} \mathrm{a}-104 \mathrm{Chl} \mathrm{b})\right]}{229}
\end{gathered}
$$

\section{2) Chemical composition}

These analyses were done in fresh leaves of faba bean shoot at 75 days from planting and also in faba bean seeds at harvest.

Mineral element concentration: Determinations of total N, P and $\mathrm{K}$ were carried out on the plant leaves were dried at $70^{\circ} \mathrm{C}$ for $48 \mathrm{hr}$ and the wet digestion of $0.2 \mathrm{~g}$ fine powder of dry material were done with sulphoric and perchloric acids as described by Piper [24]. N was determined by using the modified "Micro Kjeldahl" apparatus of Parnas and Wagner as described by Pregl [25]. P was determined spectrophotometerically by using stannous chloride method according to A.O.A.C. [26]. K was measured by flame photometer according to the method described by Brown and Lilliland [27].

Ethanol extract: Ethanol extract of leaves was used for the determination of total sugars, and total soluble phenols and total free amino acids. For preparation of ethanol extract, $0.5 \mathrm{~g}$ of dry materials were adding about $25 \mathrm{ml}$ of $95 \%$ ethanol for about $10 \mathrm{~min}$., then filtrated through a sintered glass funnel (G3). The residue was re-extracted and filtered twice with ethanol (80\%), and then the volume was adjusted to $25 \mathrm{ml}$ with ethanol (80\%).

Total sugars concentration: In ethanol extract, determination of total sugars concentrations were carried out by using the total sugars in was determined by phosphomolybdic acid method according to A.O.A.C. [26].

Total soluble phenols concentration: In ethanol extract, total soluble phenols concentration was determined by using the Folin-Ciocalteu reagent according to Swain and Hillis [28].

Total free amino acids concentration: In ethanol extract, total free amino acids concentration was determined by using ninhydrin reagent according to Moore and Stein [29].

\section{3) Seed yield and its attributes}

At harvest, a random sample of five plants was taken from each sub sub-plot to measure the following traits: Plant height $(\mathrm{cm})$, numbers of branches and pods per plant, number of seeds per pod, 100-seed weight (g) and seed yield per plant (g). Seed yield per ha (ton) was calculated from harvesting and threshing the inner three ridges of each sub sub-plot then converted to ton per ha. 


\subsection{Statistical Analysis}

Analysis of variance of the obtained results of each season was performed. The homogeneity test was conducted of error mean squares and accordingly, the combined analysis of the two experimental seasons was also carried out. The measured variables were analyzed by ANOVA using MSTATC statistical package [30]. Mean comparisons were performed using the east significant differences (L.S.D) test with a significance level of 5\% [31].

\section{Results and Discussion}

\section{A. Chemical composition and photosynthesis pigments in faba bean shoot 1) Ridge width}

Significant effects of ridge width on all the studied chemical composition and photosynthesis pigments traits in faba bean shoot were observed in the combined data across the two seasons (Table 2). Faba bean plants of wide ridge had higher shoot N, P, K, total sugars, $\mathrm{Chl}$ a and b, as well as, total free amino acids concentrations than those of the narrow one. However, high total soluble phenols and carotenoids concentrations in faba bean shoot were observed when grown in the narrow one.

These results could be attributed to wide ridge furnished suitable basic growth resources for faba bean growth and development more than the narrow one. Particularly light is one of the most important environmental factors because it regulates photosynthetic assimilation and partitioning in plants [32]. Naturally, different tissues of faba bean leaves need different requirements of essential nutrients for satisfactory their growth.

With respect to faba plants of the narrow ridge; it is likely that intra-specific competition between them was increased for basic growth resources more than those of the other one which reflected negatively on a decrease in photosynthesis and transpiration rates. Certainly, Chl content indicates indirectly the nutritional status of plants since much of leaf $\mathrm{N}$ is incorporated in Chl [33]. Consequently, it is possible to suggest that total soluble phenols and carotenoids activity in faba bean shoot were due to higher concentration of the phenolic compound and total yellow pigments against assimilates translocated into different tissues of faba bean leaves than those of the wide one.

Accordingly, it is expected that that increase of the studied chemical composition (except total soluble phenols) and Chl a and b in faba bean shoot accompanied with reduced RNase and protease activity, especially polyphenols were bonded with other organic substances such as carbohydrate or protein [34].

\section{2) Faba bean cultivars}

Faba bean cultivars were differed significantly for all the studied chemical composition and photosynthesis pigments traits in faba bean shoot except shoot $\mathrm{Chl} \mathrm{a}$ and $\mathrm{b}$ and total free amino acids concentrations in the combined data across the two seasons (Table 2). Faba bean cultivar Sakha 1 had higher shoot N, $\mathrm{P}, \mathrm{K}$ and total sugars concentrations than those of other cultivar. Meanwhile, faba 
Table 2. Effect of ridge width, faba bean cultivar, amino acids compound and their interactions on the studied chemical traits of faba bean shoot (combined data across the two seasons).

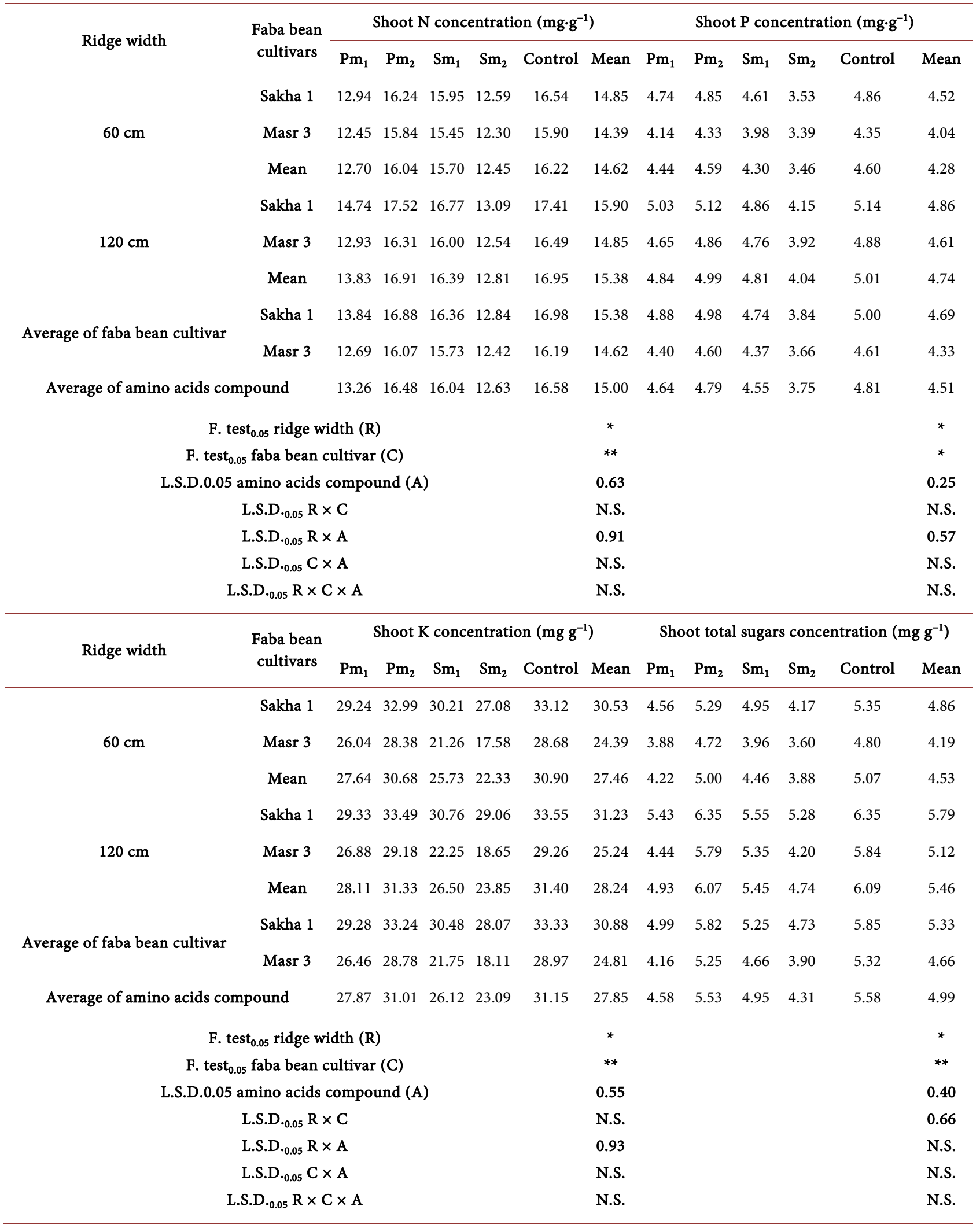




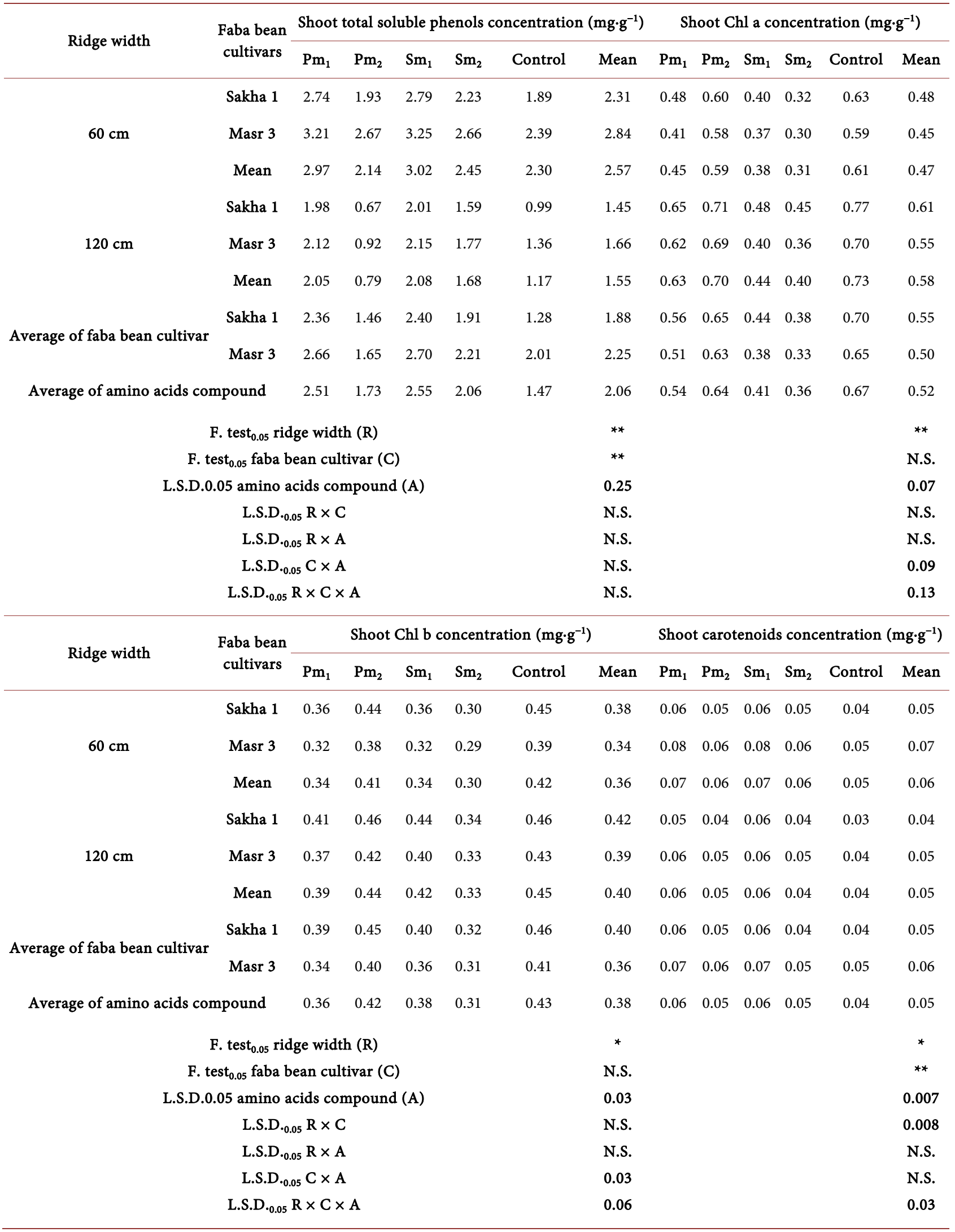




\begin{tabular}{|c|c|c|c|c|c|c|c|}
\hline \multirow{2}{*}{ Ridge width } & \multirow{2}{*}{$\begin{array}{c}\text { Faba bean } \\
\text { cultivars }\end{array}$} & \multicolumn{6}{|c|}{ Shoot total free amino acids concentration $\left(\mathrm{mg} \cdot \mathrm{g}^{-1}\right)$} \\
\hline & & $\mathrm{Pm}_{1}$ & $\mathrm{Pm}_{2}$ & $\mathrm{Sm}_{1}$ & $\mathrm{Sm}_{2}$ & Control & Mean \\
\hline \multirow{3}{*}{$60 \mathrm{~cm}$} & Sakha 1 & 0.64 & 0.83 & 0.77 & 0.56 & 0.87 & 0.73 \\
\hline & Masr 3 & 0.59 & 0.77 & 0.73 & 0.55 & 0.78 & 0.68 \\
\hline & Mean & 0.61 & 0.80 & 0.75 & 0.55 & 0.82 & 0.71 \\
\hline \multirow{3}{*}{$120 \mathrm{~cm}$} & Sakha 1 & 0.94 & 1.09 & 1.02 & 0.86 & 1.13 & 1.00 \\
\hline & Masr 3 & 0.91 & 1.07 & 0.97 & 0.81 & 1.08 & 0.97 \\
\hline & Mean & 0.93 & 1.08 & 0.99 & 0.84 & 1.10 & 0.99 \\
\hline \multirow{2}{*}{ Average of faba bean } & Sakha 1 & 0.79 & 0.96 & 0.89 & 0.71 & 1.00 & 0.87 \\
\hline & Masr 3 & 0.75 & 0.92 & 0.85 & 0.68 & 0.93 & 0.83 \\
\hline \multirow[t]{8}{*}{ Average of amir } & & 0.77 & 0.94 & 0.87 & 0.69 & 0.96 & 0.85 \\
\hline & \multicolumn{3}{|c|}{ F. test $t_{0.05}$ ridge width (R) } & & & & $* *$ \\
\hline & \multicolumn{3}{|c|}{ F. test ${ }_{0.05}$ faba bean cultivar (C) } & & & & N.S. \\
\hline & \multicolumn{3}{|c|}{ S.S.D.0.05 amino acids compound (A) } & & & & 0.19 \\
\hline & \multicolumn{3}{|c|}{ L.S.D. ${ }_{0.05} \mathrm{R} \times \mathrm{C}$} & & & & N.S. \\
\hline & \multicolumn{2}{|c|}{ L.S.D. ${ }_{0.05} \mathrm{R} \times \mathrm{A}$} & & & & & N.S. \\
\hline & \multicolumn{2}{|c|}{ L.S.D. ${ }_{0.05} \mathrm{C} \times \mathrm{A}$} & & & & & N.S. \\
\hline & \multicolumn{3}{|c|}{ L.S.D. $\cdot_{0.05} \mathrm{R} \times \mathrm{C} \times \mathrm{A}$} & & & & N.S. \\
\hline
\end{tabular}

${ }^{*}$ Significance at a level of $1 \%$ of probability $(p<0.01) *$ Significance at a level of $5 \%$ of probability $(0.01 \leq p<0.05)$ N.S. Non-Significance $(p \geq 0.05)$

bean cultivar Masr 3 had higher shoot total soluble phenols and carotenoids concentrations than the other one. It seems that genetic makeup of faba bean cultivar Sakha 1 translated into suitable some morphological and anatomical characteristics which reflected positively on canopy architecture of this cultivar than the other one. These results show that plants of faba bean cultivar Sakha 1 were able to utilize the available environmental resources that reflected positively on chemical composition in their shoots more than faba bean cultivar Masr 3 . It is expected that genetic makeup of faba bean cultivar Masr 3 had some biochemical aspects that restricted enzymatic oxidative cleavage which reflected on total soluble phenols and carotenoids concentrations in faba bean shoot.

\section{3) Amino acids compounds}

Amino acids compounds affected significantly all the studied chemical traits in faba bean shoot in the combined data across the two seasons (Table 2). Control and $\mathrm{Pm}_{2}$ had higher shoot $\mathrm{N}, \mathrm{P}, \mathrm{K}$, total sugars, Chl a and b, as well as, total free amino acids concentrations than those of the others without significant differences between them. Also, there were no significant differences between $\mathrm{Pm}_{1}$ and $\mathrm{Pm}_{2}$ for shoot $\mathrm{P}$ and total free amino acids concentrations. In other words, increasing rate of $\mathrm{Pm}$ from 1.5 to $3.0 \mathrm{~cm} \cdot \mathrm{L}^{-1}$ did not increase $\mathrm{P}$ and total free amino acids concentrations in faba bean shoot. Moreover, there were no significant differences between $\mathrm{Pm}_{1}$ and $\mathrm{Sm}_{1}$ on shoot $\mathrm{P}$, total sugars and total soluble phenols, Chl b, carotenoids and total free amino acids concentrations. On the other hand, there were no significant differences between $\mathrm{Sm}_{1}$ and control 
treatment on shoot $\mathrm{N}$ and total free amino acids concentrations. Meanwhile, there were no significant differences between $\mathrm{Sm}_{1}$ and $\mathrm{Sm}_{2}$ on shoot $\mathrm{Chl}$ a and total free amino acids concentrations. In other words, increasing rate of Sm from 3.5 to $7.0 \mathrm{~cm} \cdot \mathrm{L}^{-1}$ did not increase $\mathrm{Chl}$ a and total free amino acids concentrations in faba bean shoot. These results may be due the tested amino acids compounds were differed in their rates and composition (Table 1). It is likely that rate and composition of $\mathrm{Pm}_{2}$ which included some plant growth regulators caused rapid cell division that elongated faba bean internodes [35] by promoting roots and stem length in the plant through gibberellic acid [36], then roots grew deeper into the soil profile to extract water and soil nutrients $(\mathrm{N}, \mathrm{P}$ and $\mathrm{K})$ which reflected on shoot length. This biological situation could be enhanced by $\mathrm{K}$ citrate and micro-elements by stimulated different physiological activities.

Consequently, it is expected that foliar spraying of $\mathrm{Pm}_{2}$ lengthened the vegetative stage and thereby there was an increase in photosynthesis pigments ( $\mathrm{Chl}$ a and $b$ contents) and finally more enhance in protein synthesis. According to Fletcher et al. [37], the increase in cytokinin levels was associated with stimulated chlorophyll biosynthesis. These results are in parallel with those obtained by Ali [38] who reported that foliar application of $1 \% \mathrm{~K}$ and $1 \% \mathrm{P}$ produced highest values of $\mathrm{Chl} \mathrm{a}, \mathrm{b}$ and $\mathrm{a}+\mathrm{b}$ as compared with untreated faba bean plants. Also, El-Ghamry et al. [39] found that $\mathrm{Chl}$ a and b contents were increased significantly by amino acids compounds. Moreover, Abou EL-Yazied and Mady [40] indicated that foliar spraying with boron at $50 \mathrm{~cm} \cdot \mathrm{L}^{-1}$ increased photosynthetic pigments.

On the other hand, $\mathrm{Sm}_{1}$ had the highest shoot total soluble phenols and carotenoids concentrations compared with those of other rates. These results could be due to $\mathrm{Sm}_{1}$ that included magnesium $(\mathrm{Mg})$ activated antioxidative defense enzymes in some plant species [41]. Consequently, it is possible to suggest that this biological situation reflected positively on $\mathrm{Mg}$ availability in different tissues of faba bean plants that promoted plant growth and increased total soluble phenols concentration in faba bean shoot. It is known that $\mathrm{Mg}$ in shoots declined quickly within one day after the removal of $\mathrm{Mg}$ [42] suggesting that shoot and leaf are secondary response organs following changes in $\mathrm{Mg}$ level. It is an important to mention that decreasing rate of $\mathrm{Sm}$ from 7.0 to $3.5 \mathrm{~cm} \cdot \mathrm{L}^{-1}$ could be led to negative effects on translocation rate of sucrose from leaves to phloem which reflected positively on $\mathrm{N}, \mathrm{P}, \mathrm{K}$ and total sugars concentrations in faba bean shoot.

\section{4) Interaction between ridge width and faba bean cultivars}

Data in Table 2 show interaction between ridge width and faba bean cultivars affected significantly shoot total sugars and carotenoids concentrations in the combined data across the two seasons. Growing faba bean cultivar Sakha 1 in the wide ridge had the highest shoot total sugars concentration compared with the others. These results probably due to faba bean cultivar Sakha 1 interacted positively with the wide ridge to benefit greatly from basic growth resources which 
reflected on concentration of shoot total sugars compared with the others. Meanwhile, growing faba bean cultivar Masr 3 in the narrow ridge had the highest shoot carotenoids concentration compared with the others. These data show that each of these two factors act dependently on total sugars and carotenoids concentrations in faba bean shoot.

5) Interaction between ridge width and amino acids compounds

Data in Table 2 show interaction between ridge width and amino acids compounds affected significantly shoot $\mathrm{N}, \mathrm{P}$ and $\mathrm{K}$ concentrations in the combined data across the two seasons. The data indicate that faba bean plants that received $\mathrm{Pm}_{2}$ had the highest shoot N, P and $\mathrm{K}$ concentrations compared with those of the other treatments. Accordingly, it is expected that cytokinines and gibberellic acid in $\mathrm{Pm}_{2}$ had a major role in regulating ions and modifying the uptake movement and metabolism of nutrients within plant tissues of faba bean plants by increasing ridge width from 60 to $120 \mathrm{~cm}$. Plants have the ability to store excessive amounts of exogenously supplied hormones in form of reversible conjugates which release active hormones when the plant needs them during the growth period [43]. These results reveal that ridge width responded differently to amino acids compounds for $\mathrm{N}, \mathrm{P}$ and $\mathrm{K}$ concentrations in faba bean shoot.

6) Interaction between faba bean cultivars and amino acids compounds

Data in Table 2 show interaction between faba bean cultivars and amino acids compounds affected significantly $\mathrm{Chl} \mathrm{a}$ and $\mathrm{b}$ in faba bean shoot in the combined data across the two seasons. Faba bean cultivar Sakha 1 that received $\mathrm{Pm}_{2}$ had the highest $\mathrm{Chl} \mathrm{a}$ and $\mathrm{b}$ in faba bean shoot compared with the others. These results show that each of these two factors act dependently on the studied Chl a and $b$ in faba bean shoot.

7) Interaction among ridge width, faba bean cultivars and amino acids compounds

Data in Table 2 show interaction among ridge width, faba bean cultivars and amino acids compounds affected significantly photosynthesis pigments in faba bean shoot in the combined data across the two seasons. Growing faba bean cultivar Sakha 1 in the wide ridge that received $\mathrm{Pm}_{2}$ had the highest shoot $\mathrm{Chl}$ a and $\mathrm{b}$ compared with the others. These results probably due to genetic makeup of faba bean cultivar Sakha 1 that received $\mathrm{Pm}_{2}$ interacted positively with wide ridge to increase $\mathrm{Chl} a$ and $\mathrm{b}$ in faba bean shoot. Meanwhile, growing faba bean cultivar Masr 3 in the narrow ridge that received $\mathrm{Sm}_{1}$ recorded the highest shoot carotenoids compared with the others. Response of plant to plant growth regulators vary with varieties, environmental conditions, physiological and nutritional status, as well as, stage of development and endogenous hormonal balance [44]. These results reveal that ridge width $\mathrm{x}$ faba bean cultivars $\mathrm{x}$ amino acids compounds had significant effects on photosynthesis pigments in faba bean shoot.

\section{B. Seed yield and its attributes}

1) Ridge width

Significant effects of ridge width on all the studied traits of seed yield and its 
Table 3. Effect of ridge width, faba bean cultivar, amino acids compound and their interactions on seed yield and its attributes (combined data across the two seasons).

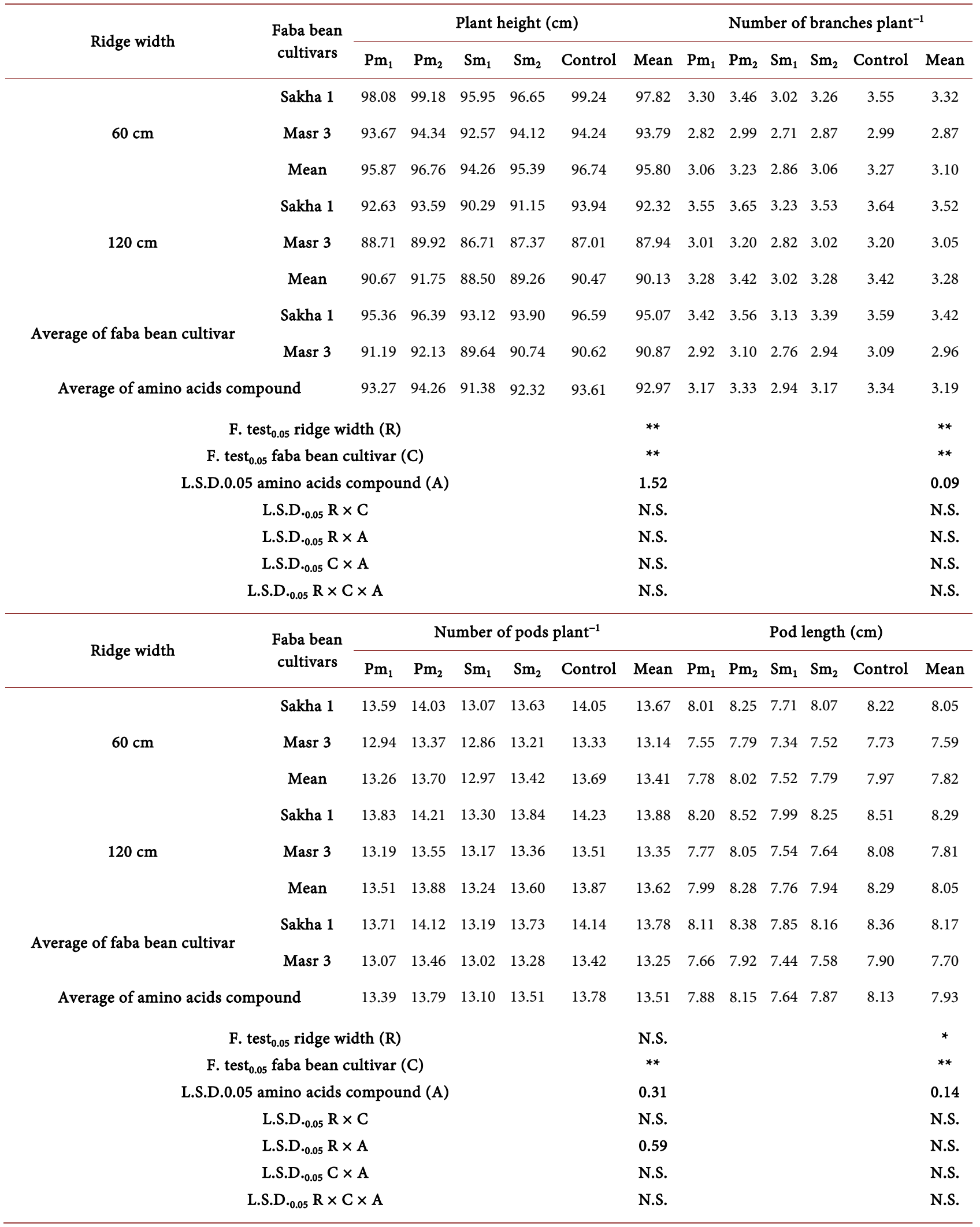


H. F. Y. Mohamed et al.

Continued

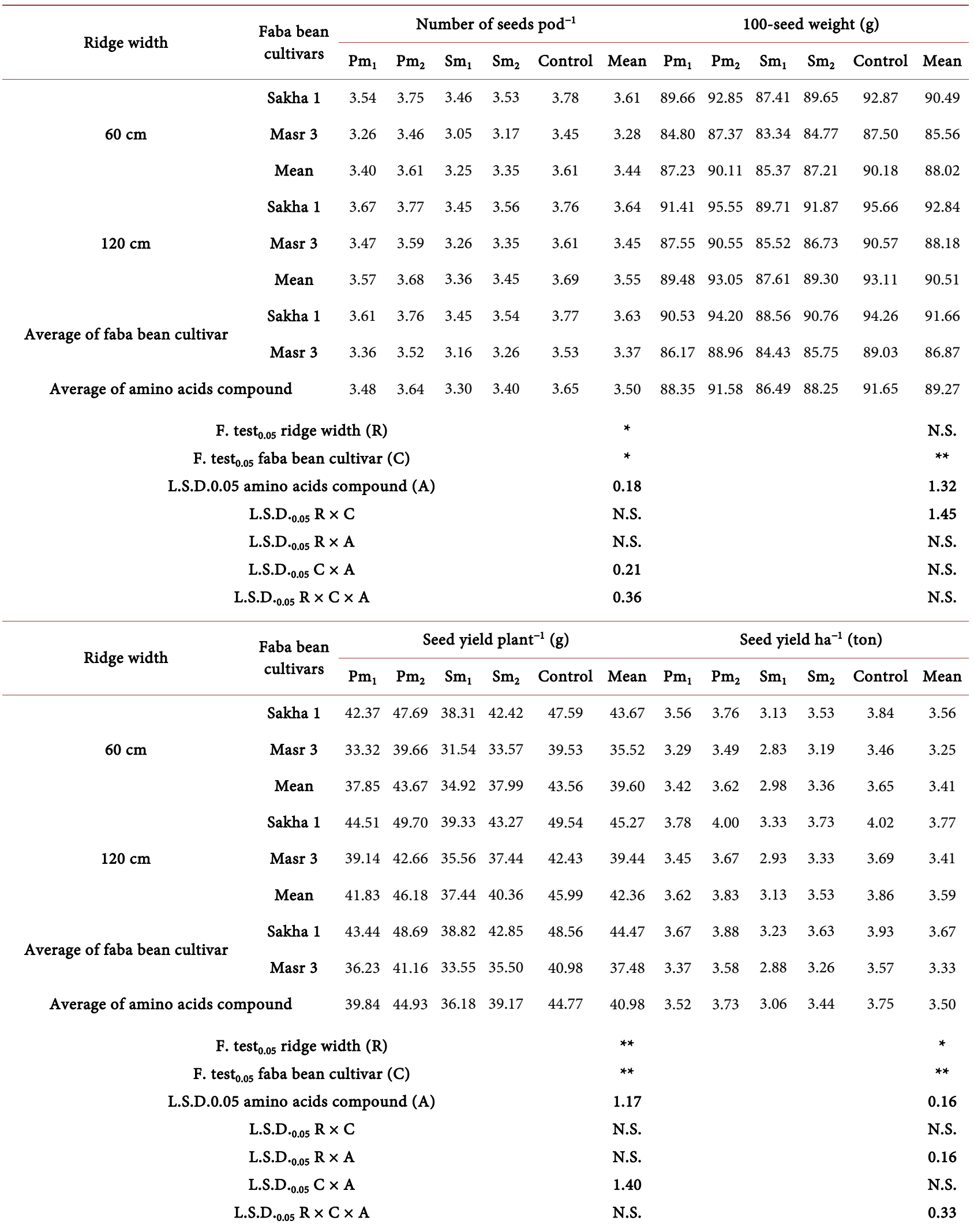

${ }^{*}$ Significance at a level of $1 \%$ of probability $(\mathrm{p}<0.01) *$ Significance at a level of $5 \%$ of probability $(0.01 \leq \mathrm{p}<0.05)$ N.S. Non-Significance $(\mathrm{p} \geq 0.05)$. 
attributes except number of pods plant ${ }^{-1}$ and 100 -seed weight in the combined data across the two seasons (Table 3). Faba bean plants of the wide ridge had higher values of number of branches plant ${ }^{-1}$, pod length, number of seeds $\operatorname{pod}^{-1}$, seed yields plant ${ }^{-1}$ and $\mathrm{ha}^{-1}$ than those of narrow one; meanwhile plant height had opposite trend. Faba bean plants of the wide ridge increased branches number plant ${ }^{-1}$ by $5.80 \%$, pod length by $2.94 \%$, seeds number pod $^{-1}$ by $3.19 \%$, seed yield plant ${ }^{-1}$ by $6.96 \%$ and seed yield $\mathrm{ha}^{-1}$ by $5.27 \%$ than those of the other one. These results may be due to faba bean plants that grown in wide ridge benefited greatly from environmental basic resources that reflected positively on their efficiency in photosynthetic process more than those of narrow one.

\section{2) Faba bean cultivars}

Faba bean cultivars were differed significantly for all the studied traits in the combined data across the two seasons (Table 3). Faba bean cultivar Sakha 1 had higher plant height, numbers of branches and pods plant ${ }^{-1}$, pod length, number of seeds pod $^{-1}, 100$-seed weight, seed yields plant ${ }^{-1}$ and $\mathrm{ha}^{-1}$ than those of the other cultivar. These variations between the tested two cultivars probably due to genetic makeup of each cultivar translated into suitable some morphological and physiological characteristics which responded differently to environmental conditions. Similar results were reported by Mohamed and El-Abbas [45], Bakry et al. [46] and Safina [8] who reported there were significant differences among faba bean cultivars in seed yield and yield attributes traits.

\section{3) Amino acids compounds}

Amino acids compounds affected significantly all the studied traits in the combined data across the two seasons (Table 3). These results reveal that control and $\mathrm{Pm}_{2}$ had higher plant height, numbers of branches and pods plant ${ }^{-1}$, pod length, number of seeds pod ${ }^{-1}, 100$-seed weight, seed yields plant ${ }^{-1}$ and ha ${ }^{-1}$ than those of the others without significant differences between them. However, there were no significant differences between $\mathrm{Pm}_{1}$ and $\mathrm{Pm}_{2}$ on plant height which indicating the increase in rate of Pm from 1.5 to $3.0 \mathrm{~cm} \cdot \mathrm{L}^{-1}$ had similar effect on this trait. Also, there were no significant differences between $\mathrm{Pm}_{1}$ and $\mathrm{Sm}_{1}$ on plant height, numbers of branches and pods plant ${ }^{-1}$, pod length, 100-seed weight, seed yields plant ${ }^{-1}$ and $\mathrm{ha}^{-1}$. Moreover, there were no significant differences between $\mathrm{Sm}_{2}$ and control treatment on plant height, number of pods plant ${ }^{-1}$. Furthermore, there were no significant differences between $\mathrm{Sm}_{1}$ and $\mathrm{Sm}_{2}$ on plant height and number of seeds $\operatorname{pod}^{-1}$ which indicating the increase in rate of $S \mathrm{~m}$ from 3.5 to $7.0 \mathrm{~cm} \cdot \mathrm{L}^{-1}$ had similar effect on these traits.

These results may be due to $\mathrm{Pm}_{2}$ is compound that have high rate of amino acids, riboflavin, cytokinines, gibberellic acid, $\mathrm{K}$ citrate and micro-elements led to an increase in dry matter accumulation during growth and development. Particularly, boron as microelement plays a key role in higher plants by facilitating the short- and long-distance transport of sugar via the formation of borate-sugar complexes [47]. It is known that boron deficiency in crops is more widespread than the deficiency of any other micronutrients [48]. Also, zinc is a micronutrient 
needed in small amounts by crop plants, but its important in crop production has increased in recent years [49]. In this concern, Mady [50] showed that many growth faba bean traits as number of leaves plant ${ }^{-1}$, dry weights of stems and leaves plant ${ }^{-1}$, as well as, total leaf area were enhanced by foliar application of zinc. Moreover, Al-Whaibi et al. [51] found that seed yield attributes were increased by gibberellic acid application.

With respect to Sm, number of branches plant ${ }^{-1}$, pod length, number of seeds pod $^{-1}$, seed yields plant ${ }^{-1}$ and $\mathrm{ha}^{-1}$ were increased by increasing rate of Sm from 3.5 to $7.0 \mathrm{~cm} \cdot \mathrm{L}^{-1}$. These results could be attributed to increase in rate of $\mathrm{Sm}$ from 3.5 to $7.0 \mathrm{~cm} \cdot \mathrm{L}^{-1}$ increased translocation rate of sucrose from leaves to phloem which reflected positively carbohydrate accumulation in the attributes of seed yield where Cakmak et al. [52] showed that Mg deficiency restricted the carbon flow to the sink organs and caused carbohydrate accumulation in the source leaves.

\section{4) Interaction between ridge width and faba bean cultivars}

Data in Table 3 show interaction between ridge width and faba bean cultivars affected significantly 100 -seed weight in the combined data across the two seasons. Growing faba bean cultivar Sakha 1 in the wide ridge had the highest 100-seed weight compared to the others. It seems that faba bean cultivar Sakha 1 interacted positively with wide ridge to furnish better translocation of available assimilates from source to sink during reproductive stage of faba bean compared with the others. These results show that each of these two factors act dependently on 100 -seed weight.

\section{5) Interaction between ridge width and amino acids compounds}

Data in Table 3 show interaction between ridge width and amino acids compounds affected significantly number of pods plant ${ }^{-1}$ and seed yield ha ${ }^{-1}$ in the combined data across the two seasons. Growing faba bean plants in the wide ridge that received $\mathrm{Pm}_{2}$ had the highest number of pods plant ${ }^{-1}$ and seed yield $\mathrm{ha}^{-1}$ compared with the others. These results reveal that ridge width responded differently to amino acids compounds for number of pods plant ${ }^{-1}$ and seed yield $\mathrm{ha}^{-1}$.

6) Interaction between faba bean cultivars and amino acids compounds

Data in Table 3 show interaction between faba bean cultivars and amino acids compounds affected significantly number of seeds pod $^{-1}$ and seed yield plant ${ }^{-1}$ in the combined data across the two seasons. Faba bean cultivar Sakha 1 that received $\mathrm{Pm}_{2}$ had the highest number of seeds pod ${ }^{-1}$ and seed yield plant ${ }^{-1}$ compared with the others. These results show that each of these two factors act dependently on number of seeds pod ${ }^{-1}$ and seed yield plant ${ }^{-1}$.

7) Interaction among ridge width, faba bean cultivars and amino acids compounds

Data in Table 3 show interaction among ridge width, faba bean cultivars and amino acids compounds affected significantly number of seeds $\operatorname{pod}^{-1}$ and seed yield ha ${ }^{-1}$ only in the combined data across the two seasons. These results may 
be attributed to growing faba bean cultivar Sakha 1 in the wide ridge that received $\mathrm{Pm}_{2}$ had the highest number of seeds pod ${ }^{-1}$ and seed yield ha ${ }^{-1}$ compared with the others. It seems that faba bean cultivar Sakha 1 that received $\mathrm{Pm}_{2}$ interacted positively with the wide ridge to enhance source-sink relationship and stimulates the translocation of photoassimilates to sink thereby helping in effective flower formation and ultimately enhancing number of seeds pod $^{-1}$. These results reveal that each of these three factors act dependently on number of seeds $\operatorname{pod}^{-1}$ and seed yield ha ${ }^{-1}$.

C. Chemical composition in faba bean seeds

1) Ridge width

Significant effects of ridge width on all the studied chemical composition in faba bean seeds traits were observed in the combined data across the two seasons (Table 4). Faba bean plants of the wide ridge had higher seed N, P, K, total sugars and total free amino acids concentrations than those of the narrow one; meanwhile the reverse was true for seed total soluble phenols concentration. The wide ridge increased seed $\mathrm{N}, \mathrm{P}, \mathrm{K}$, total sugars and total free amino acids concentrations by $10.96 \%, 37.44 \%, 9.60 \%, 13.71 \%$ and $32.67 \%$ than those of the narrow one. Conversely, the wide ridge decreased seed total soluble phenols concentration by $31.62 \%$ than the other one. These results may be due to faba bean plants of wide ridge decreased intra-specific competition between them for basic growth resources which activated enzyme polyphenol oxidase and led to degradation and consequent losses of total soluble phenols in faba bean seeds.

\section{2) Faba bean cultivars}

Faba bean cultivars were differed significantly for all the studied chemical composition in faba bean seeds traits in the combined data across the two seasons (Table 3). Faba bean cultivar Sakha 1 had higher seed N, P, K, total sugars and total free amino acids concentrations than those of other one; meanwhile the reverse was true for seed total soluble phenols concentration. Faba bean cultivar Sakha 1 recorded higher seed N, P, K, total sugars and total free amino acids concentrations by $11.48 \%, 22.81 \%, 14.07 \%$ and $8.44 \%$, respectively, more than faba bean cultivar Masr 3. With respect to seed total soluble phenols concentration, the results show that total soluble phenols concentration depended on moisture content in faba bean seeds probably due to seeds of Masr 3 cultivar had lower moisture than the other one. Consequently, the observed differences in chemical composition in faba bean seeds between the two cultivars are likely to primarily reflect genotypic variation.

\section{3) Amino acids compounds}

Amino acids compounds affected significantly all the studied chemical composition in faba bean seeds traits in the combined data across the two seasons (Table 3). Control and $\mathrm{Pm}_{2}$ had higher seed $\mathrm{N}, \mathrm{P}, \mathrm{K}$, total sugars and total free amino acids concentrations than those of the others without significant differences between them; meanwhile the reverse was true for seed total soluble phenols concentration. However, there were no significant differences between $\mathrm{Pm}_{1}$ 
Table 4. Effect of ridge width, faba bean cultivar, amino acids compound and their interactions on quality of faba bean seeds (combined data across the two seasons).

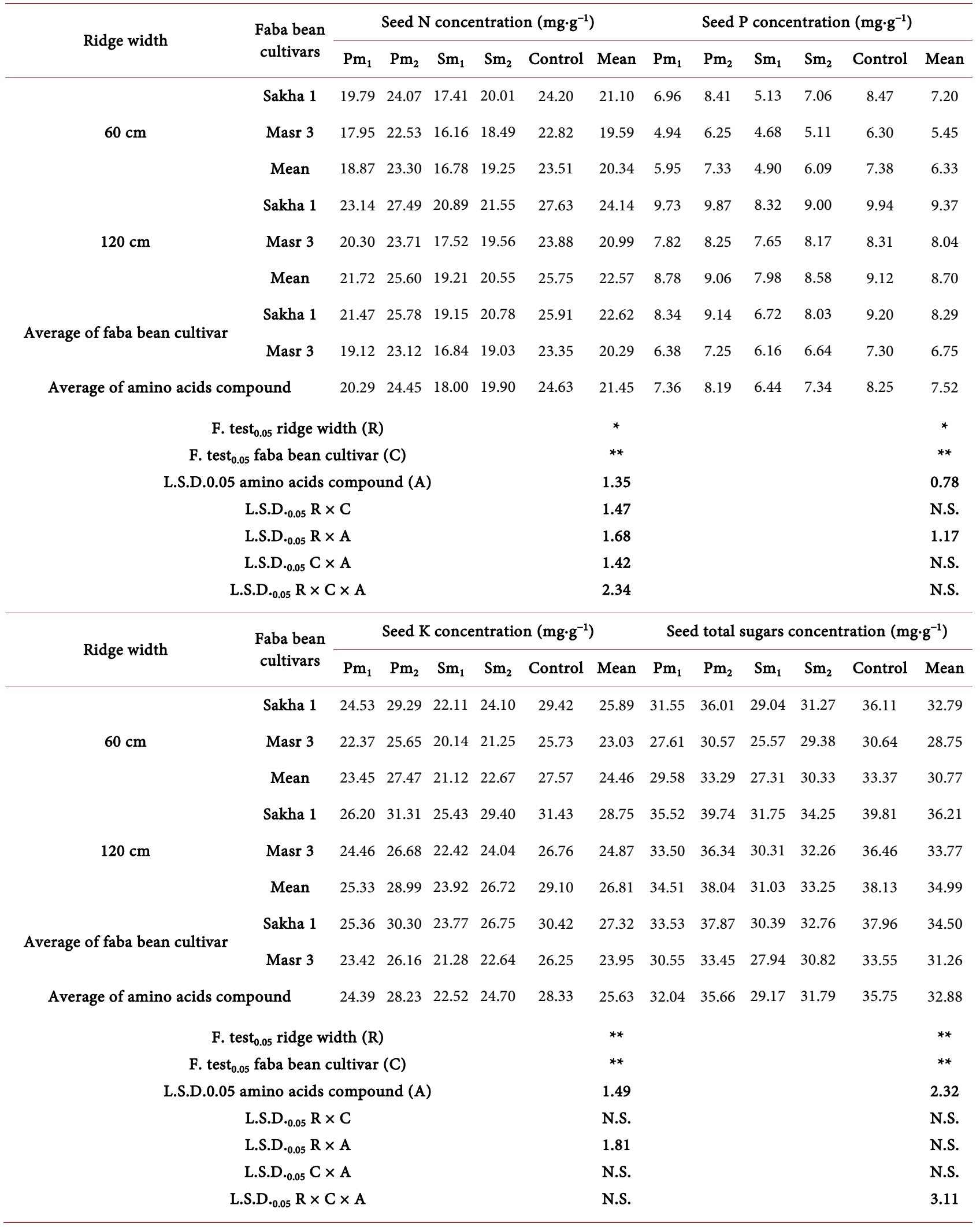


Continued

\begin{tabular}{|c|c|c|c|c|c|c|c|c|c|c|c|c|c|}
\hline \multirow{2}{*}{ Ridge width } & \multirow{2}{*}{$\begin{array}{c}\text { Faba bean } \\
\text { cultivars }\end{array}$} & \multicolumn{6}{|c|}{ Seed total soluble phenols concentration $\left(\mathrm{mg} \cdot \mathrm{g}^{-1}\right)$} & \multicolumn{6}{|c|}{ Seed total free amino acids concentration $\left(\mathrm{mg} \cdot \mathrm{g}^{-1}\right)$} \\
\hline & & $\mathrm{Pm}_{1}$ & $\mathrm{Pm}_{2}$ & $\mathrm{Sm}_{1}$ & $\mathrm{Sm}_{2}$ & Cont. & Mean & $\mathrm{Pm}_{1}$ & $\mathrm{Pm}_{2}$ & $\mathrm{Sm}_{1}$ & $\mathrm{Sm}_{2}$ & Cont. & Mean \\
\hline \multirow{3}{*}{$60 \mathrm{~cm}$} & Sakha 1 & 1.25 & 1.08 & 1.26 & 1.14 & 1.05 & 1.15 & 6.92 & 8.29 & 6.52 & 7.80 & 8.35 & 7.58 \\
\hline & Masr 3 & 1.27 & 1.13 & 1.31 & 1.19 & 1.08 & 1.19 & 5.97 & 7.20 & 5.72 & 7.02 & 7.26 & 6.63 \\
\hline & Mean & 1.26 & 1.10 & 1.28 & 1.16 & 1.06 & 1.17 & 6.45 & 7.74 & 6.12 & 7.41 & 7.80 & 7.10 \\
\hline \multirow{3}{*}{$120 \mathrm{~cm}$} & Sakha 1 & 0.85 & 0.74 & 0.83 & 0.71 & 0.81 & 0.78 & 9.07 & 10.16 & 8.69 & 10.00 & 10.19 & 9.62 \\
\hline & Masr 3 & 0.88 & 0.77 & 0.87 & 0.72 & 0.84 & 0.81 & 8.83 & 9.69 & 8.58 & 9.31 & 9.73 & 9.23 \\
\hline & Mean & 0.86 & 0.75 & 0.85 & 0.71 & 0.82 & 0.80 & 8.95 & 9.92 & 8.63 & 9.66 & 9.96 & 9.42 \\
\hline \multirow{2}{*}{$\begin{array}{c}\text { Average of faba } \\
\text { bean cultivar }\end{array}$} & Sakha 1 & 1.07 & 0.95 & 1.09 & 1.01 & 0.90 & 1.00 & 8.00 & 9.23 & 7.60 & 8.90 & 9.27 & 8.60 \\
\hline & Masr 3 & 1.05 & 0.91 & 1.04 & 0.97 & 0.88 & 0.97 & 7.40 & 8.44 & 7.15 & 8.16 & 8.49 & 7.93 \\
\hline \multicolumn{2}{|c|}{$\begin{array}{l}\text { Average of amino acids } \\
\text { compound }\end{array}$} & 1.06 & 0.93 & 1.06 & 0.99 & 0.89 & 0.98 & 7.70 & 8.83 & 7.37 & 8.53 & 8.88 & 8.26 \\
\hline \multicolumn{6}{|c|}{ F. test t.05 $_{\text {ridge width (R) }}$} & & * & & & & & & ** \\
\hline \multicolumn{6}{|c|}{ F. test ${ }_{0.05}$ faba bean cultivar $(\mathrm{C})$} & & * & & & & & & ** \\
\hline \multicolumn{6}{|c|}{ L.S.D.0.05 amino acids compound (A) } & & 0.02 & & & & & & 1.14 \\
\hline \multicolumn{6}{|c|}{ L.S.D. $.0 .05 \mathrm{R} \times \mathrm{C}$} & & N.S. & & & & & & N.S. \\
\hline \multicolumn{6}{|c|}{ L.S.D.0.05 $\mathrm{R} \times \mathrm{A}$} & & 0.47 & & & & & & 1.49 \\
\hline \multicolumn{6}{|c|}{ L.S.D.0.05 ${ }_{\cdot 0 .} \mathrm{A}$} & & 0.23 & & & & & & 0.84 \\
\hline \multicolumn{6}{|c|}{ L.S.D. $.0 .05 \mathrm{R} \times \mathrm{C} \times \mathrm{A}$} & & 0.58 & & & & & & 2.45 \\
\hline
\end{tabular}

${ }^{*}$ Significance at a level of $1 \%$ of probability $(p<0.01) *$ Significance at a level of $5 \%$ of probability $(0.01 \leq p<0.05)$ N.S. Non-Significance $(p \geq 0.05)$.

and $\mathrm{Pm}_{2}$ on total free amino acids meaning that this trait responded similarly to the tested rates of $\mathrm{Pm}$. Meanwhile, there were no significant differences $\mathrm{Pm}_{1}$ and $\mathrm{Sm}_{2}$ on seed $\mathrm{N}, \mathrm{P}, \mathrm{K}$, total sugars and total free amino acids. Moreover, there were no significant differences between $\mathrm{Sm}_{2}$ and control treatment on total free amino acids. The results of this study suggest that $\mathrm{Pm}_{2}$ could activate translocation of the absorbed nutrients into the seed as a result of improvements in physiological attributes in plants that received high rate of $\mathrm{Pm}$. With respect to total soluble phenols concentration in faba bean seeds, $\mathrm{Sm}_{1}$ had higher seed total soluble phenols concentration than others. It is important to mention that there were no significant differences between $\mathrm{Sm}_{1}$ and $\mathrm{Pm}_{1}$ for total soluble phenols concentration in faba bean seeds. It is known that tyrosinase inhibition activity is significantly correlated with total phenols and antioxidant capacity [53]. On the other hand, increasing rate of Sm from 3.5 to $7.0 \mathrm{~cm} \cdot \mathrm{L}^{-1}$ increased seed $\mathrm{N}, \mathrm{P}$, $\mathrm{K}$, total sugars and total free amino acids concentrations was due to increase in translocation rate of $\mathrm{N}, \mathrm{P}, \mathrm{K}$ and total sugars concentrations from leaves to seed during seed filling period.

\section{4) Interaction between ridge width and faba bean cultivars}

Interaction between ridge width and faba bean cultivars affected significantly $\mathrm{N}$ concentration in faba bean seeds in the combined data across the two seasons (Table 4). Growing faba bean cultivar Sakha 1 in the wide ridge had the highest 
seed $\mathrm{N}$ concentration compared with the others. It seems that this interaction had not significant effects on seed quality. These results reveal that each of these two factors act dependently on $\mathrm{N}$ concentration in faba bean seeds.

\section{5) Interaction between ridge width and amino acids compounds}

Data in Table 4 show interaction between ridge width and amino acids compounds affected significantly $\mathrm{N}, \mathrm{P}, \mathrm{K}$, total soluble phenols and total free amino acids concentrations in faba bean seeds in the combined data across the two seasons. Growing faba bean plants in the wide ridge that received $\mathrm{Pm}_{2}$ had the highest seed N, P, K and total free amino acids concentrations compared with the others. These results could be attributed to faba bean plants of the wide ridge that received $\mathrm{Pm}_{2}$ furnished better growth and development conditions for faba bean plants which reflected positively on enlargement, filling and maturation of seed development compared with the others. From the other point, growing faba bean plants in the narrow ridge that received $\mathrm{Sm}_{1}$ had the highest seed total soluble phenols concentration compared with the others. These results reveal that ridge width responded differently to amino acids compounds for $\mathrm{N}, \mathrm{P}, \mathrm{K}$, total soluble phenols and total free amino acids concentrations in faba bean seeds.

6) Interaction between faba bean cultivars and amino acids compounds

Data in Table 4 show interaction between faba bean cultivars and amino acids compounds affected significantly $\mathrm{N}$, total soluble phenols and total free amino acids concentrations in faba bean seeds in the combined data across the two seasons. Faba bean cultivar Sakha 1 that received $\mathrm{Pm}_{2}$ had the highest $\mathrm{N}$ and total free amino acids concentrations in faba bean seeds compared with the others. Meanwhile, faba bean cultivar Masr 3 that received $\mathrm{Sm}_{1}$ had the highest total soluble phenols concentration in faba bean seeds indicating good antioxidants compared with the others. The concentration and presence of these compounds in plants varied depending upon many factors, including plant genetic variation, soil composition, cultural factors and climate [54]. These results show that each of these two factors act dependently on $\mathrm{N}$, total soluble phenols and total free amino acids concentrations in faba bean seeds.

7) Interaction among ridge width, faba bean cultivars and amino acids compounds

Data in Table 4 show interaction among ridge width, faba bean cultivars and amino acids compounds affected significantly $\mathrm{N}$, total sugars, total soluble phenols and total free amino acids concentrations in faba bean seeds in the combined data across the two seasons. Growing faba bean cultivar Sakha 1 in the wide ridge that received $\mathrm{Pm}_{2}$ had the highest $\mathrm{N}$, total sugars and total free amino acids concentrations in faba bean seeds compared with the others. Obviously, growing faba bean cultivar Sakha 1 in the wide ridge with foliar spraying of $\mathrm{Pm}_{2}$ achieved high quality. On the other hand, growing faba bean cultivar Masr 3 in the narrow ridge that received $\mathrm{Sm}_{1}$ achieved good antioxidants in faba bean seeds. Although the soil nutrients are required for normal growth and development of crop, integrating both organic and inorganic chemicals for quality production 
should be considered [55]. These results reveal that there were significant effects of ridge width $\times$ faba bean cultivars $\times$ amino acids compounds on $\mathrm{N}$, total sugars, total soluble phenols and total free amino acids concentrations in faba bean seeds.

\section{Conclusion}

Our results can be concluded that the limiting factor for increasing seed quality and antioxidants of the tested faba bean cultivars depends on rate and composition of amino acids. Faba bean plants of wide ridge had higher shoot and seed chemical composition except total soluble phenols than those of the narrow one. Also, Faba bean cultivar Sakha 1 gave higher N, P, K and total sugars concentrations in shoot and seeds, as well as, seed yield and its attributes than Masr 3. Moreover, faba bean plants that received $\mathrm{Sm}_{1}$ recorded the highest antioxidants in their seeds; meanwhile faba bean plants that received $\mathrm{Pm}_{2}$ had the highest seed quality compared with the other treatments. Growing two rows of faba bean cultivar Sakha 1 in $120 \mathrm{~cm}$ ridge width that received $3.0 \mathrm{~cm} \cdot \mathrm{L}^{-1}$ of power mix increased seed yield and quality.

\section{Conflicts of Interest}

The authors declare no conflicts of interest regarding the publication of this paper.

\section{References}

[1] Pritchard, P.J., Dryburgh, E.A. and Wilson, B.J. (1973) Carbohydrates of Spring and Winter Field Beans. (Vicia faba L.). Journal of the Science of Food and Agriculture, 24, 663-668. https://doi.org/10.1002/jsfa.2740240605

[2] Chavan, J.K., Kute, L.S. and Kadam, S.S. (1989) Broad Bean. In: Salankhe, D.K. and Kaddam, S.S., Eds., Handbook of World Food Legumes. Nutritional Chemistry Processing Technology and Utilization, Vol. 1, CRC Press, Boca Raton, 223-245.

[3] Jambunathan, R., Blain, H.L., Dhindsa, K.H., Hussein, L.A., Kogure, K., Li-Juan, L. and Youssef, M.M. (1994) Diversifying Use of Cool Season Food Legumes through Processing. In: Muehlbauer, F.J. and Kaiser, W.J., Eds., Expanding the Production and Use of Cool Season Food Legumes, Kluwer Academic Publishers, Dordrecht, 98-112. https://doi.org/10.1007/978-94-011-0798-3_4

[4] Matthews, P. and Marcellos, H. (2003) Faba Bean. Agfact P4.2.7., Second Edition 2003, Division of Plant Industries, New South Wales Agriculture, Australia, 1-12. http://www.dpi.nsw.gov.au/_data/assets/pdf_file/0004/157729/faba-bean-pt1.pdf

[5] FAOSTAT (2009) Food and Agriculture Organization. http://faostat.fao.org/site/567/default.aspx\#ancor

[6] Luo, Y., Xie, W., Jin, X., Tao, B., Chen, Q. and Zhu, W. (2013) Impact of Sprouting Pretreatment on Phytic Acid and Polyphenol Level of Faba Bean (Vicia faba L.) flour. International Food Research Journal, 20, 1133-1137.

[7] Abd Rahman, Rehab A.M. (2014) Effect of Plant Population and Distribution on Yield and Yield Components of Five Faba Bean Genotypes. Journal of Plant Production, Mansoura University, 5, 1965-1972. 
[8] Safina, S.A. (2017) Effect of Ridge Width and Cropping System on Productivity and Land Use Efficiency in Faba Bean-Flax Intercrops. Egyptian Journal of Agronomy, 39, 357-381. https://doi.org/10.21608/agro.2017.1591.1073

[9] Sjodin, J. (1981) Protein Quantity and Quality in Vicia faba. International Conference on Fababean, Cairo, 7-11 March 1981.

[10] Davies, D.D. (1982) Physiological Aspects of Protein Turnover. Encyclopedia of Plant Physiology, 45, 481-487.

[11] Schnitzer, M. (2001) The Chemistry of Nitrogen in Soils. In: Keinan, E. and Schechter, I., Eds., Chemistry for the 21 st Century, Wiley-VCH GmbH, Weinheim, 117-129.

[12] Rai, V.K. (2002) Role of Amino Acids in Plant Responses to Stress. Biologia Plantarum, 45, 471-478. https://doi.org/10.1023/A:1022308229759

[13] Ibrahim, M.E., Bekheta, M.A., El-Moursi, A. and Gafar, N.A. (2010) Improvement of Growth and Seed Yield Quality of Vicia faba L. Plants as Affected by Application of Some Bioregulators. Australian Journal of Basic and Applied Sciences, 1, 657-666.

[14] Abdel-Mawgoud, A.M.R., El-Bassiouny, A.M., Ghoname, A. and Abou-Hussein, S.D. (2011) Foliar Application of Amino Acids and Micronutrients Enhance Performance of Green Bean Crop under Newly Reclaimed Land Conditions. Australian Journal of Basic and Applied Sciences, 5, 51-55.

[15] Ghaith, R.H. and Galal, R.M. (2014) Response of Pea Plant (Pisum sativum L.) Growth and Yield for Spraying of Amino Acid and Boron. Egyptian Journal of Applied Science, 29, 154-173.

[16] Shafeek, M.R., Hafez, M.M., Mahmoud, A.R. and Ali, A.H. (2014) Comparative Effect on N-Fixing Bacterial with Foliar Application of Amino Acid Mixed on Growth and Yield of Pea Plants (Pisum sativum L.). Middle East Journal of Applied Sciences, 4, 755-761.

[17] Zewail, R.M.Y. (2014) Effect of Seaweed Extract and Amino Acid on Growth and Productivity and Some Biocostituents of Common Bean (Phaseolus vulgaris L.) Plants. Journal of Plant Production-Mansoura University, 5, 1441-1453.

[18] Dillard, C.J. and German, J.B. (2000) Phytochemicals: Nutraceuticals and Human Health. Journal of the Science of Food and Agriculture, 80, 1744-1756.

[19] Amarowicz, R. and Weidner, S. (2009) Biological Activity of Grapevine Phenolic Compounds. In: Roubelakis, K.A. and Angelakis, Eds., Grapevine Molecular Physiology \& Biotechnology, Springer Science + Business Media B.V., Heraklion, 2nd Edition, 389-405. https://doi.org/10.1007/978-90-481-2305-6_14

[20] Chaieb, N., Johannes, L.G., Montserrat, L.M., Mohamed, B. and Manuel, V. (2011) Polyphenol Content and Antioxidant Capacity of Thirteen Faba Bean (Vicia faba L.) Genotypes Cultivated in Tunisia. Food Research International, 44, 970-977. https://doi.org/10.1016/j.foodres.2011.02.026

[21] Siah, S.D., Konczak, I., Agboola, S., Wood, J.A. and Blanchard, C.L. (2012) In Vitro Investigations of the Potential Health Benefits of Australian-Grown Faba Beans (Vicia faba L.): Chemopreventative Capacity and Inhibitory Effects on the Angiotensin-Converting Enzyme, Aglucosidase and Lipase. British Journal of Nutrition, 108, S123-S134.

[22] Black, C.A. (1965) Methods of Soil Analysis. ASA, SSSA, Madison.

[23] Nornai, R. (1982) Formula for Determination of Chloorophyllus Pigments Extracted with N.N Dimethyl Formamide. Plant Physiology, 69, 1376-1381. 
[24] Piper, C.S. (1947) Soil and Plant Analysis. The University of Adelaide, Adelaide.

[25] Pregl, F. (1945) Quantitative-Organic Micro-Analysis. 4th Edition, J. \& A. Churchill, London.

[26] A.O.A.C. (1975) Official Methods of Analysis. Association of Official Analytical Chemists, Washington DC.

[27] Brown, J.D. and Lilliland, O. (1964) Rapid Kaus Determination of Potassium and Sodium in Plant Materials and Soil Extracts by Flame Photometer. Proceedings of the American Society for Horticultural Science, 48, 341-346.

[28] Swain, T. and Hillis, W.E. (1959) The Phenolic Constituents of Prunus domestica. I. The Quantitative Analysis of Phenolic Constituents. Journal of the Science of Food and Agriculture, 10, 63-68. https://doi.org/10.1002/jsfa.2740100110

[29] Moore, S. and Stein, W.H. (1954) A Modified Ninhydrin Reagent for the Photometric Determination of Amino Acids and Related Compounds. The Journal of Biological Chemistry, 211, 907-913.

[30] Freed, R.D. (1991) MSTATC Microcomputer Statistical Program. Michigan State Univ., East Lansing.

[31] Gomez, K.A. and Gomez, A.A. (1984) Statistical Procedures for Agricultural Research. John Willey and Sons, New York.

[32] Slewinski, T.L. and Braun, D.M. (2010) Current Perspectives on the Regulation of Whole-Plant Carbohydrate Partitioning. Plant Science, 178, 341-349. https://doi.org/10.1016/j.plantsci.2010.01.010

[33] Moran, J.A., Mitchell, A.K., Goodmanson, G. and Stockburger, K.A. (2000) Differentiation among Effects of Nitrogen Fertilization Treatments on Conifer Seedlings by Foliar Reflectance: A Comparison of Methods. Tree Physiology, 20, 1113-1120. https://doi.org/10.1093/treephys/20.16.1113

[34] Saharan, K., Khetarpaul, N. and Bishnoi, S. (2002) Antinutrients and Protein Digestibility of Faba Bean and Rice Bean as Affected by Soaking, Dehulling and Germination. Journal of Food Science and Technology, 39, 418-422.

[35] Sachs, R.M. (1965) Stem Elongation. Annual Review of Plant Physiology, 16, 73-96. https://doi.org/10.1146/annurev.pp.16.060165.000445

[36] Azuma, T., Ueno, S., Uchid, N. and Yasuda, T. (1997) Gibberellin Induced Elongation and Osmoregulation in Internodes of Floating Rice. Physiologia Plantarum, 99, 517-522. https://doi.org/10.1111/j.1399-3054.1997.tb05351.x

[37] Fletcher, R.A., Gilley, A., Davis, T.D. and Sankhla, N. (2000) Triazoles as Plant Growth Regulators and Stress Protectants. Horticultural Reviews, 24, 55-138.

[38] Ali, O.A.M. (2005) Physiological Studies on Growth, Flowering and Productivity of Some Faba Bean (Vicia faba L.) Varieties. M.Sc. Thesis, Fac. of Agric., Menoufia University, Shebeen El-Kom.

[39] El-Ghamry, A.M., Abd El-Hai, K.M. and Ghoneem, Kh.M. (2009) Amino and Humic Acids Promote Growth, Yield and Disease Resistance of Faba Bean Cultivated in Clayey Soil. Australian Journal of Basic and Applied Sciences, 3, 731-739.

[40] Abou EL-Yazied, A. and Mady, M.A. (2012) Effect of Boron and Yeast Extract Foliar Application on Growth, Pod Setting and Both Green Pod and Seed Yield of Broad Bean (Vicia faba L). Journal of Applied Sciences Research, 8, 1240-1251.

[41] Tewari, R.K., Kumar, P. and Sharma, P.N. (2006) Magnesium Deficiency Induced Oxidative Stress and Antioxidant Responses in Mulberry Plants. Scientia Horticulturae, 108, 7-14. https://doi.org/10.1016/j.scienta.2005.12.006 
[42] Niu, Y., Chai, R., Liu, L.J., Jin, G.L., Liu, M., Tang, C.X. and Zhang, Y.C. (2014) Magnesium Availability Regulates the Development of Root Hairs in Arabidopsis thaliana (L.) Heynh. Plant, Cell \& Environment, 37, 2795-2813. https://doi.org/10.1111/pce.12362

[43] Uddeen, M.M. (2009) Effect of Plant Growth Regulators on Growth and Yield of Mukhikachu. Bangladesh Journal of Agricultural Research, 34, 233-238.

[44] Verma, P. and Sen, N.L. (2008) The Impact of Plant Growth Regulators on Growth and Biochemical Constituents of Coriander (Coriandrum sativum L.). Journal of Herbs, Spices and Medicinal Plants, 14, 144-153. https://doi.org/10.1080/10496470802598685

[45] Mohamed, M.R. and El-Abbas, E. (2005) Response of Three Faba Bean Cultivars (Vicia faba L.) to Different Nitrogen Sources under P-Biofertilizer and Micronutrients Addition. The Journal of Agricultural Science, Mansoura University, 30, 8277-8292.

[46] Bakry, B.A., Elewa, T.A., El Karamany, M.F., Zeidan, M.S. and Tawfik, M.M. (2011) Effect of Row Spacing on Yield and Its Components of Some Faba Bean Cultivars under Newly Reclaimed Sandy Soil Conditions. World Journal of Agricultural Sciences, 7, 68-72.

[47] Dugger, W.M. (1983) Boron in Plant Metabolism. Encyclopedia of Plant Physiology, 15, 626-650.

[48] Gupta, U.C. (1993) Boron and Its Role in Crop Production. CRC Press, Boca Raton, 53-85.

[49] Fageria, N.K. (2009) The Use of Nutrients in Crop Plants. Pesquisa Agropecuária Brasileira, 40, 1211-1215. https://doi.org/10.1590/S0100-204X2005001200008

[50] Mady, M.A. (2009) Effect of Foliar Application with Yeast Extract and Zinc on Fruit Setting and Yield of Faba Bean (Vicia faba L). Journal of Biological Chemistry and Environmental Sciences, 4, 109-127.

[51] Al-Whaibi, M.H., Siddiqui, M.H., Al Amri, A. and Basalah, M.O. (2010) Performance of Faba Bean under Calcium and Gibbrellic Acid Application. The International Journal of Developmental Biology, 4, 60-63.

[52] Cakmak, I., Hengeler, C. and Marschner, H. (1994) Changes in Phloem Export of Sucrose in Leaves in Response to Phosphorus, Potassium and Magnesium Deficiency in Bean Plants. Journal of Experimental Botany, 45, 1251-1257. https://doi.org/10.1093/jxb/45.9.1251

[53] Turco, I., Ferretti, G. and Bacchet, T. (2016) Review of the Health Benefits of Faba Bean (Vicia faba L.) Polyphenols. Journal of Food and Nutrition Research, 55, 283-293.

[54] Haselgrove, L., Botting, D., Van Heeswijck, R., Hoj, P.B., Dry, P.R., Ford, C. and Iland, P.G. (2000) Canopy Microclimate and Berry Composition: The Effect of Bunch Exposure on the Phenolic Composition of Vitis vinifera L cv. Shiraz Grape Berries. Australian Journal of Grape and Wine Research, 6, 141-149. https://doi.org/10.1111/j.1755-0238.2000.tb00173.x

[55] Falticeanu, M. (2004) Contributions for Improvement of Field Growing Technologies in Some Vegetable Species. Doctor's Degree Thesis, University of Agriculture-Iassy. 